\title{
IDENTIFICATION OF ENHANCING FACTORS FOR INCREASING THE POWER COMPETITIVENESS OF SMALL MEDIUM INDUSTRY OF BATIK IN SIDOARJO DISTRICT WITH INTEGRATION OF GREEN INNOVATION APPROACH AND ISM
}

\author{
${ }^{1}$ Ida Kusnawati Tjahjani, ${ }^{2}$ Abdul Hakim, ${ }^{3}$ Bagyo Yanuwiadi, ${ }^{4}$ Dias Satria \\ ${ }^{1,2,3,4}$ Brawijaya University, Malang, East Java, Indonesia \\ Email : echamail21@gmail.com
}

\begin{abstract}
Purpose: Identify the inhibiting factors of increasing competitiveness in the small and medium batik industry in the district of Sidoarjo.

Design/methodology/approach: The data collection process uses a questionnaire compiled with the Green Innovation approach with five main variables, Green Resource, Green Process, Green Product, Green Innovation, and Competitive Advantage. Green Innovation is a process of continuous innovation that considers the integration of the environment, finance, social systems in the company from the stage of ideas through research and development and commercialization that affect new products, services, technology, business, and organizational models. Determination of alternatives and strategy analysis using the Interpretative Structural Modeling (ISM) approach is a method that uses the opinions of experts on the questionnaire that has been distributed.
\end{abstract}

Findings: Based on the analysis results, 14 inhibiting factors and six priority levels were obtained, with the highest value of the power driver in the training and outreach factor (10) as the main inhibiting factor in increasing competitiveness. Therefore, it requires the involvement of all parties related to the batik SMEs to improve their competitiveness and the strategies they choose.

Research limitations/implications: This research was conducted at the Small and Medium Industry (IKM) of batik in the district of Sidoarjo, which is one of 15 districts in East Java who chose One Village One Product $(O V O P)$ as strategies increase the power of competitiveness. Number of samples relative small if it is compared with the number of batik SME di East Java.

Practical implications: Result of this research can be used to increase competitiveness of SME Batik in East Java and Indonesia.

Originality/value: This research is original.

Paper type: Research paper.

Keyword: Enter key words or phrases in alphabetical order, separated by commas and maximum of six words. IKM, OVOP, Green Innovation, ISM, Inhibiting Factors

Received: July $25^{\text {th }}, 2020$

Revised: August $17^{\text {th }}, 2020$

Published: September $30^{\text {th }}, 2020$ 


\section{INTRODUCTION}

As one of the cultural heritages, Batik has made Indonesia an international name since it was designated by UNESCO as an Intangible Cultural Heritage of Humanity in Abu Dhabi on October 2, 2009, which has the potential to support the people's economy, because it has a significant influence on world demand, turning into a classy business (Republika.co.id, 2009), a market leader, and has comparative and competitive competitiveness with several export destination countries, including the United States, Belgium, Britain, Japan, and South Korea.

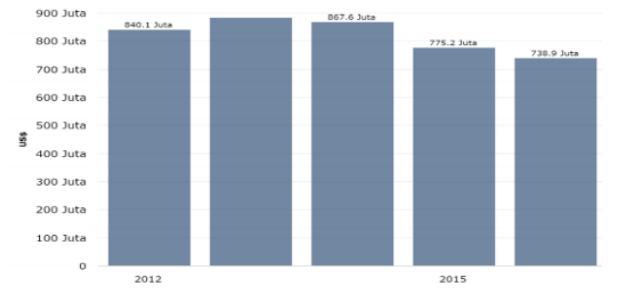

Figure 1. Export Value of Written Batik 2012 - 2016

Recognition from UNESCO can end, if not maintained, its existence and sustainability (Pradito, Jusuf, \& Atik, 2010). This is what supports the spread of the batik industry in 101 centers, namely Central Java, West Java, East Java, Yogyakarta, Sumatra, Kalimantan, Sulawesi, and Papua (WartaEkonomi.co.id, 2018) ; (Elim, 2018).

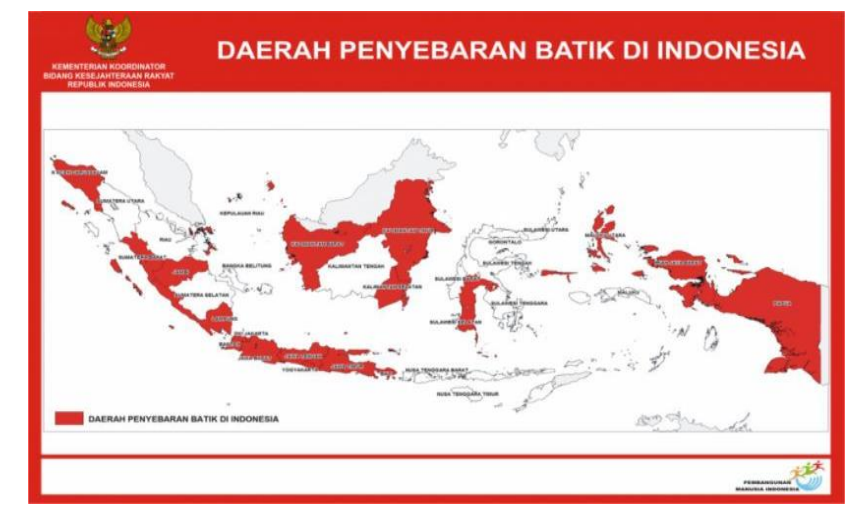

Figure 2. Map of the Distribution of Written Batik in Indonesia

In line with Presidential Regulation 28/2008 on the National Industrial Development Policy which stipulates that each regency/city must develop regional commodity commodities and the launch of One Village One Product (OVOP) by the Governor of East Java in 2008 which opens opportunities for 15 districts/cities to implement the strategy to improve the competitiveness of selected batik (Kamil, 2011), namely:

Table 1. Competitiveness Improvement Strategies

\begin{tabular}{lll}
\hline No. & Regency / City & Competitiveness Strategies \\
\hline 1. & Bangkalan & KID \\
2. & Banyuwangi & KID \\
3. & Magetan & IK \\
4. & Pacitan & IK \\
5. & Pamekasan & IK \\
6. & Sidoarjo & OVOP \\
7. & Sumenep & KID \\
8. & Trenggalek & IK \\
9. & Tuban & OVOP \\
10. & Mojokerto & OVOP \\
\hline
\end{tabular}

Information:

$\mathrm{KID}=$ Regional Core Competencies 
$\mathrm{IK}=$ Creative Industry

OVOP = One Village One Product

Sidoarjo Regency is one of the regencies in the northern part of East Java Province which was dubbed the "Indonesian SME City" in 2013 because it has 30 types of superior products Tjahjani, Mochammad Hatta, \& Wahyudi (2017) as well as the only regency that had five batik centers with distinctive features and different characteristics in several districts since the Dutch era, namely Sekardangan and Jets wrote batik in Sidoarjo District, Kenongo printed batik in Tulangan district, Kedung Cangkring written batik in Jabon District (Tjahjani, Hatta, \& Wahyudi, 2018) and Peranakan Chinese batik. However, only Jets, Sekardangan and Kenongo batik centers have been able to rise since 1980 (Ida Kusnawati Tjahjani, Baharuddin, \& Yuliawati, 2019), although in conditions that are quite alarming with various problems encountered, including:

Table 2. Problems and Effects of Written Batik

\begin{tabular}{|c|c|}
\hline Issue & ipact \\
\hline Slow regeneration of craftsmen (Wardani, 2015) & 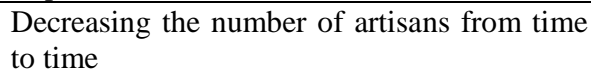 \\
\hline $\operatorname{man}$ & \\
\hline & era \\
\hline $\begin{array}{l}\text { Batik appreciation is only a formality (Bahruddin \& Nugraha, } \\
\text { 2013) }\end{array}$ & $\begin{array}{l}\text { Lack of understanding the val } \\
\text { and production process }\end{array}$ \\
\hline $\begin{array}{l}\text { Art, complicated, manual and non-standard processes } \\
\text { (Widayati, 2013) }\end{array}$ & $\begin{array}{l}\text { Work with heart, long processes, and } \\
\text { expensive }\end{array}$ \\
\hline $\begin{array}{l}\text { ork environment that is not ergonomic (I. K. } \\
\text { 17) }\end{array}$ & $\begin{array}{l}\text { Productivity, muscle fatigue, } \\
\text { occupational diseases }\end{array}$ \\
\hline ment of mative (Domolon 2008 ) & \\
\hline erivan & $\begin{array}{l}\text { desires of consumers } \\
\text { Ratyaningrum, 2016). }\end{array}$ \\
\hline iction results (Bahruddin \& & Not \\
\hline $\begin{array}{l}\text { tion administration, catalogs, sup } \\
\text { and marketing methods (I. K. Tja }\end{array}$ & $\begin{array}{l}\text { coverage, sales turnover, } \\
\text { con, business process }\end{array}$ \\
\hline $\begin{array}{l}\text { Capital, market access, raw materials, labor \& technological } \\
\text { mastery (Pawitan, 2012) }\end{array}$ & $\begin{array}{l}\text { iency), quality, and } \\
\text { (Mizar, Mawardi, } \\
08 \text { ) }\end{array}$ \\
\hline
\end{tabular}

In addition to these problems, currently making batik waste also becomes a focus, because it produces three waste at once, namely: 1). Liquid waste from washing, coloring, chloride, dyeing, and fixing fixanol (Rochma \& Titah, 2017);(Kurniawan, Purwanto, \& Sudarno, 2014). 2). Waste gas, from fabric cutting, washing, drying, mola, nyanting, soaking, staining, drying, mbironi, nglorod, fixing soaking fixanol, and drying and 3). Solid waste arising from cutting cloth, mbironi, mola, and nglorod. As awareness of the environment, health, market demands, and the availability of dyes from various types of plants are available in place of synthetic dyes.

The purpose of this study is to identify the inhibiting factors for increasing competitiveness in the small and medium batik industry in Sidoarjo Regency with the integration of the Green Innovation and Interpretative Structural Modeling (ISM) approach.

\section{METHODOLOGY}

\section{A. Green Innovation}

Green Innovation is a process of continuous innovation with consideration of environmental, financial, social integration in company systems from the idea stage of research and development (R\&D) and commercialization that influences new products, services, technology, business and organizational models (Charter \& Clark, 2007), which was applied to the questionnaire according to the literature and expert opinion as an inhibiting factor. 


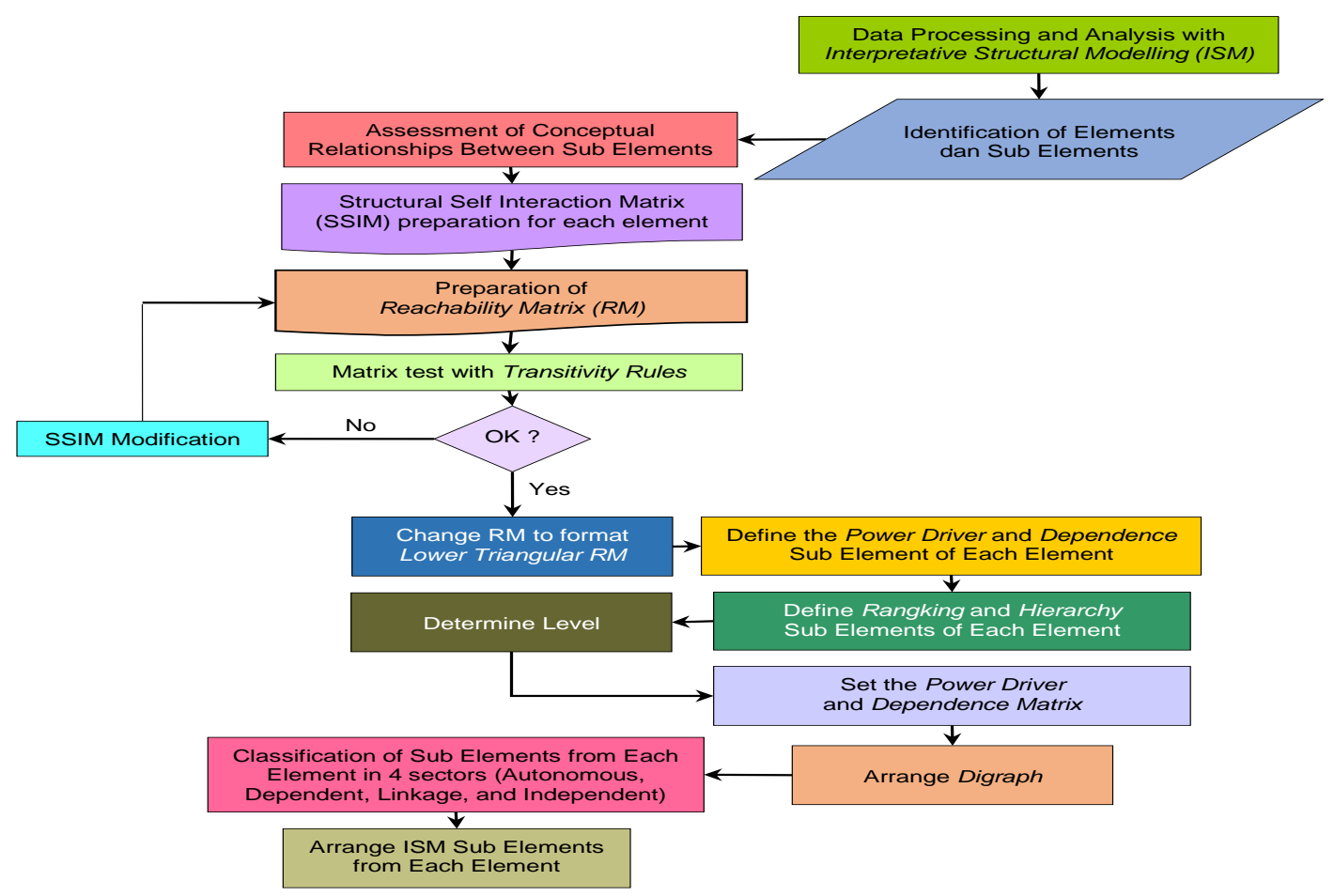

Figure 3. ISM Method (Darmawan, 2017)

\section{B. Interpretative Structural Modeling (ISM)}

ISM is a decision-making analysis tool in complex situations by grouping and linking it on a map to strategic policy planning Santoso \& Darwanto (2015) by prioritizing qualitative factors and proposing hierarchical structures based on sequence and category (Rimantho \& Rosdiana, 2018), whose application:

Table 3. Application of ISM and Its Strategic Issues

\begin{tabular}{|c|c|}
\hline Classification & Strategic Issues discussed \\
\hline & $\begin{array}{l}\text { The Objectives of Waste Management in India: A Futures Inquiry } \\
\text { (Sharma, Gupta and Sushil, 1995) }\end{array}$ \\
\hline ISM on Waste Management & $\begin{array}{l}\text { The Development of a Cleaner Production Model and Applied } \\
\text { Management Solutions for the Pharmaceutical Industry (Zadeh, Aleagha } \\
\text { and Nia, 2018) }\end{array}$ \\
\hline $\begin{array}{l}\text { ISM in The Innovation } \\
\text { Process }\end{array}$ & $\begin{array}{l}\text { Modeling and Forming Relationships Between the Obstacles Faced in the } \\
\text { Innovation Process in Turkey (Doç et al., 2010) }\end{array}$ \\
\hline $\begin{array}{l}\text { ISM for a Community } \\
\text { Development }\end{array}$ & $\begin{array}{l}\text { Model of a Coastal Area Community Development Program by a } \\
\text { Government Power Plant (Premana, 2010) }\end{array}$ \\
\hline ISM for SMEs & $\begin{array}{l}\text { Interpretive Structural Modeling of Identified Barriers to Lean } \\
\text { Implementation in SMEs (Shrimali, Soni and Pawar, 2018) } \\
\text { Interpretive Structural Modeling of Identified Succes Factor to Lean } \\
\text { Implementation in SMEs (Shrimali, 2019) }\end{array}$ \\
\hline ISM for Written Batik & $\begin{array}{l}\text { Analysis of The Obstacles to Implementing Cleaner Production in the } \\
\text { Semarang Batik Village Using the ISM Approach (Pujotomo, Sriyanto and } \\
\text { Widyawati, 2017) }\end{array}$ \\
\hline
\end{tabular}

This Interpretative Structural Modeling published by J. Warfield in 1973 Pradito et al. (2010) is a Soft System Methodology or SSM Sumadyo (2016) with stages:

1. Breaking down the program to several sub-elements

2. Determine the contextual relationship between sub-elements. For each element that shows a pairwise comparison, use expert opinion.

3. Arranging the Structural Self Interaction (SSIM) matrix using symbols, namely:

$\mathrm{V}=$ factor $\mathrm{i}$ influences factor $\mathrm{j}$

$\mathrm{A}=$ factor $\mathrm{i}$ is influenced by factor $\mathrm{j}$

$\mathrm{X}=$ factors $\mathrm{i}$ and $\mathrm{j}$ influence each other

$\mathrm{O}=$ factors $\mathrm{I}$ and $\mathrm{j}$ do not affect each other 
4. Make the Reachability Matrix (RM) and replace the symbols $\mathrm{V}, \mathrm{A}, \mathrm{X}$, and $\mathrm{O}$ with numbers 1 or 0 .

5. Calculates based on the rules of transitivity, so that the SSIM matrix is corrected until a closed matrix (loop matrix) occurs.

6. Determine the level of sub-elements for each element according to vertical and horizontal levels.

7. Arranging a Driver-Power-Dependence (DPD) matrix and Level Partitions.

8. Classifying sub-elements into four sectors Diabat, Govindan, \& Panicker (2012), namely:

a. AUTONOMOUS (weak driver - weak dependent variables),

b. DEPENDENT (weak driver - weak dependent variables),

c. LINKAGE (strong driver - strongly dependent variables),

d. INDEPENDENT (strong driver - strongly dependent variables)

\section{RESULTS AND DISCUSSION}

Based on the results of the survey, literature, and expert opinion, there are 14 indicators, which are factors that inhibit the increase in competitiveness in the Small and Medium Industry (IKM) of written batik.

Table 4. Inhibiting Factors

\begin{tabular}{|c|c|c|c|}
\hline No. & Variable & Indicators & Source \\
\hline 1 & $\begin{array}{l}\text { Green } \\
\text { Resources } \\
\text { Innovation }\end{array}$ & $\begin{array}{l}\text { Potential Human Resources } \\
\text { The availability of main and supporting raw material } \\
\text { Equiment used today } \\
\text { Availability of information needed } \\
\text { Efficiency and effectiveness cost }\end{array}$ & $\begin{array}{l}\text { (Grant, 1999) } \\
\text { (Yuan \& Zhang, 2013) }\end{array}$ \\
\hline 2. & $\begin{array}{l}\text { Green } \\
\text { Process } \\
\text { Innovation }\end{array}$ & $\begin{array}{l}\text { Concern for environmental impacts } \\
\text { Efficiency and effectiveness of resources (energy, water, } \\
\text { and etc) }\end{array}$ & $\begin{array}{l}\text { (Baumann, Boons, \& Bragd, } \\
\text { 2002) } \\
\text { (Chen, 2008) }\end{array}$ \\
\hline 3. & $\begin{array}{l}\text { Green } \\
\text { Product } \\
\text { Innovation }\end{array}$ & $\begin{array}{l}\text { The use materials that can be recycled } \\
\text { Training and outreach from the government to SME's }\end{array}$ & (Dangelico \& Pujari, 2010) \\
\hline 5. & $\begin{array}{l}\text { Competitive } \\
\text { Advantages }\end{array}$ & $\begin{array}{l}\text { Competitive, Cheap Price, Surplus Value, Scarcity, Not } \\
\text { easy to imitate, and Unique } \\
\text { Choice of strategy }\end{array}$ & $\begin{array}{l}\text { (Jin, Hopkins, \& Wittmer, } \\
2010) \\
\text { (Wu, Lin, Chien, \& Hung, } \\
\text { 2011) }\end{array}$ \\
\hline
\end{tabular}

\section{A. SSIM Matrix}

SSIM is compiled based on the opinion of experts and the literature on the questionnaire in the form of symbols to show the relationship between factors $i$ and $j$. is an inhibiting factor in increasing competitiveness in IKM written batik:

Table 5. Inhibiting Factors 


\begin{tabular}{|c|c|c|c|c|c|c|c|c|c|c|c|c|c|c|}
\hline In & $\mathbf{1}$ & $\mathbf{2}$ & $\mathbf{3}$ & $\mathbf{4}$ & $\mathbf{5}$ & $\mathbf{6}$ & $\mathbf{7}$ & $\mathbf{8}$ & $\mathbf{9}$ & $\mathbf{1 0}$ & $\mathbf{1 1}$ & $\mathbf{1 2}$ & $\mathbf{1 3}$ & $\mathbf{1 4}$ \\
\hline 1 & & $\mathrm{~V}$ & $\mathrm{~V}$ & $\mathrm{X}$ & $\mathrm{V}$ & $\mathrm{X}$ & $\mathrm{O}$ & $\mathrm{X}$ & $\mathrm{V}$ & $\mathrm{A}$ & $\mathrm{A}$ & $\mathrm{A}$ & $\mathrm{X}$ & $\mathrm{V}$ \\
\hline 2 & & & $\mathrm{O}$ & $\mathrm{X}$ & $\mathrm{X}$ & $\mathrm{V}$ & $\mathrm{X}$ & $\mathrm{A}$ & $\mathrm{X}$ & $\mathrm{A}$ & $\mathrm{A}$ & $\mathrm{X}$ & $\mathrm{X}$ & $\mathrm{A}$ \\
\hline 3 & & & & $\mathrm{X}$ & $\mathrm{X}$ & $\mathrm{A}$ & $\mathrm{X}$ & $\mathrm{X}$ & $\mathrm{O}$ & $\mathrm{A}$ & $\mathrm{A}$ & $\mathrm{A}$ & $\mathrm{V}$ & $\mathrm{X}$ \\
\hline 4 & & & & & $\mathrm{~V}$ & $\mathrm{X}$ & $\mathrm{A}$ & $\mathrm{A}$ & $\mathrm{A}$ & $\mathrm{A}$ & $\mathrm{X}$ & $\mathrm{A}$ & $\mathrm{X}$ & $\mathrm{X}$ \\
\hline 5 & & & & & & $\mathrm{X}$ & $\mathrm{X}$ & $\mathrm{X}$ & $\mathrm{X}$ & $\mathrm{A}$ & $\mathrm{O}$ & $\mathrm{X}$ & $\mathrm{A}$ & $\mathrm{V}$ \\
\hline 6 & & & & & & & $\mathrm{~V}$ & $\mathrm{~A}$ & $\mathrm{~V}$ & $\mathrm{~A}$ & $\mathrm{~A}$ & $\mathrm{O}$ & $\mathrm{X}$ & $\mathrm{A}$ \\
\hline 7 & & & & & & & & $\mathrm{X}$ & $\mathrm{X}$ & $\mathrm{A}$ & $\mathrm{O}$ & $\mathrm{O}$ & $\mathrm{O}$ & $\mathrm{X}$ \\
\hline 8 & & & & & & & & & $\mathrm{~V}$ & $\mathrm{~A}$ & $\mathrm{~A}$ & $\mathrm{O}$ & $\mathrm{A}$ & $\mathrm{X}$ \\
\hline 9 & & & & & & & & & & $\mathrm{~A}$ & $\mathrm{~A}$ & $\mathrm{O}$ & $\mathrm{V}$ & $\mathrm{V}$ \\
\hline 10 & & & & & & & & & & & $\mathrm{~A}$ & $\mathrm{O}$ & $\mathrm{X}$ & $\mathrm{X}$ \\
\hline 11 & & & & & & & & & & & & $\mathrm{O}$ & $\mathrm{X}$ & $\mathrm{V}$ \\
\hline 12 & & & & & & & & & & & & & $\mathrm{X}$ & $\mathrm{O}$ \\
\hline 13 & & & & & & & & & & & & & & $\mathrm{X}$ \\
\hline 14 & & & & & & & & & & & & & & \\
\hline
\end{tabular}

\section{B. Reachability Matrix}

The following stages are from the reachability matrix:

1. Replace the symbols $\mathrm{V}, \mathrm{A}, \mathrm{X}$ and $\mathrm{O}$ on $\mathrm{RM}$ with numbers 1 or 0 , according to the provisions:

- If the symbol $\mathrm{V}$, then entries $(\mathrm{i}, \mathrm{j})$ are one and entries $(\mathrm{j}, \mathrm{i})$ are 0.

- If the symbol $A$, then entries $(i, j)$ are 0 and entries $(j, i)$ are 1

- If the symbol $X$, then entries $(i, j)$ are one and entries $(j, i)$ are 1.

- If the symbol $\mathrm{O}$, then entries $(\mathrm{i}, \mathrm{j})$ are 0 , and entries $(\mathrm{j}, \mathrm{i})$ are 0 .

2. Determine the driven power (DP), dependency (Dpd), and level partitions (LP) to create the ISM model.

Table 6. Reachability Matrix

\begin{tabular}{lllllllllllllllll}
\hline In & 1 & 2 & 3 & 4 & 5 & 6 & 7 & 8 & 9 & 10 & 11 & 12 & 13 & 14 & DP & LP \\
\hline 1 & 1 & 1 & 1 & 1 & 1 & 1 & 0 & 1 & 1 & 0 & 0 & 0 & 1 & 1 & 10 & 3 \\
2 & 0 & 1 & 0 & 1 & 1 & 1 & 1 & 1 & 1 & 0 & 0 & 1 & 1 & 0 & 9 & 4 \\
3 & 0 & 0 & 1 & 1 & 1 & 0 & 1 & 1 & 0 & 0 & 0 & 0 & 1 & 1 & 7 & 6 \\
4 & 1 & 1 & 1 & 1 & 1 & 1 & 0 & 0 & 0 & 0 & 1 & 0 & 1 & 1 & 9 & 4 \\
5 & 0 & 1 & 1 & 0 & 1 & 1 & 1 & 1 & 1 & 0 & 0 & 1 & 0 & 1 & 9 & 4 \\
6 & 1 & 0 & 1 & 1 & 1 & 1 & 1 & 0 & 1 & 0 & 0 & 0 & 1 & 0 & 8 & 5 \\
7 & 0 & 1 & 1 & 1 & 1 & 0 & 1 & 1 & 1 & 0 & 0 & 0 & 0 & 1 & 8 & 5 \\
8 & 1 & 1 & 1 & 1 & 1 & 1 & 1 & 1 & 1 & 0 & 0 & 0 & 0 & 1 & 10 & 3 \\
9 & 0 & 1 & 0 & 1 & 1 & 0 & 1 & 0 & 1 & 0 & 0 & 0 & 1 & 1 & 7 & 6 \\
10 & 1 & 1 & 1 & 1 & 1 & 1 & 1 & 1 & 1 & 1 & 0 & 0 & 1 & 1 & 12 & 1 \\
11 & 1 & 1 & 1 & 1 & 0 & 1 & 0 & 1 & 1 & 1 & 1 & 0 & 1 & 1 & 11 & 2 \\
12 & 1 & 1 & 1 & 1 & 1 & 0 & 0 & 0 & 0 & 0 & 0 & 1 & 1 & 0 & 7 & 6 \\
13 & 1 & 1 & 0 & 1 & 1 & 1 & 0 & 1 & 0 & 1 & 1 & 1 & 1 & 1 & 11 & 2 \\
14 & 0 & 1 & 1 & 1 & 0 & 1 & 1 & 1 & 0 & 1 & 0 & 0 & 1 & 1 & 9 & 4 \\
Dpd & 8 & 12 & 11 & 13 & 12 & 10 & 9 & 10 & 9 & 4 & 3 & 4 & 11 & 11 & & \\
\hline
\end{tabular}

\section{Model ISM}

In this ism model describes the hierarchical structure between factors at all levels: 


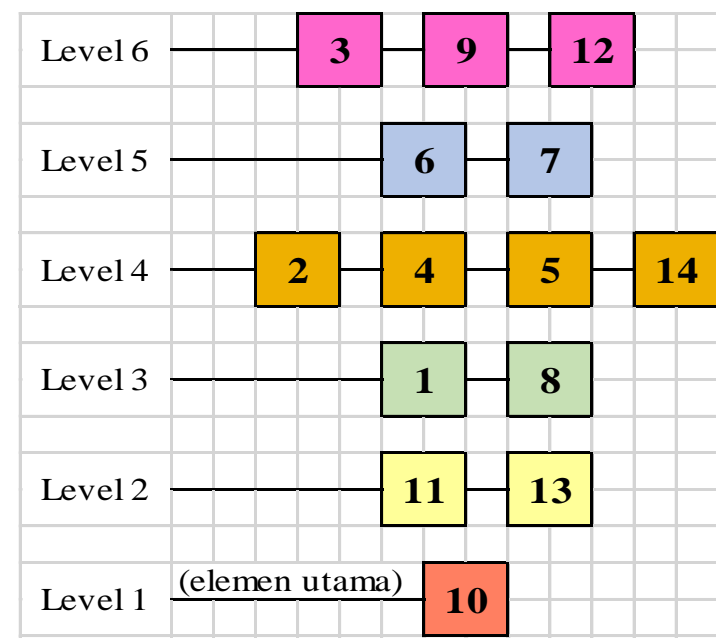

Figure 4. The Hierarchical Structure Between Factors

D. MICMAC Analysis

From the value of driven power and dependence, the Micmac analysis can be described as follows:

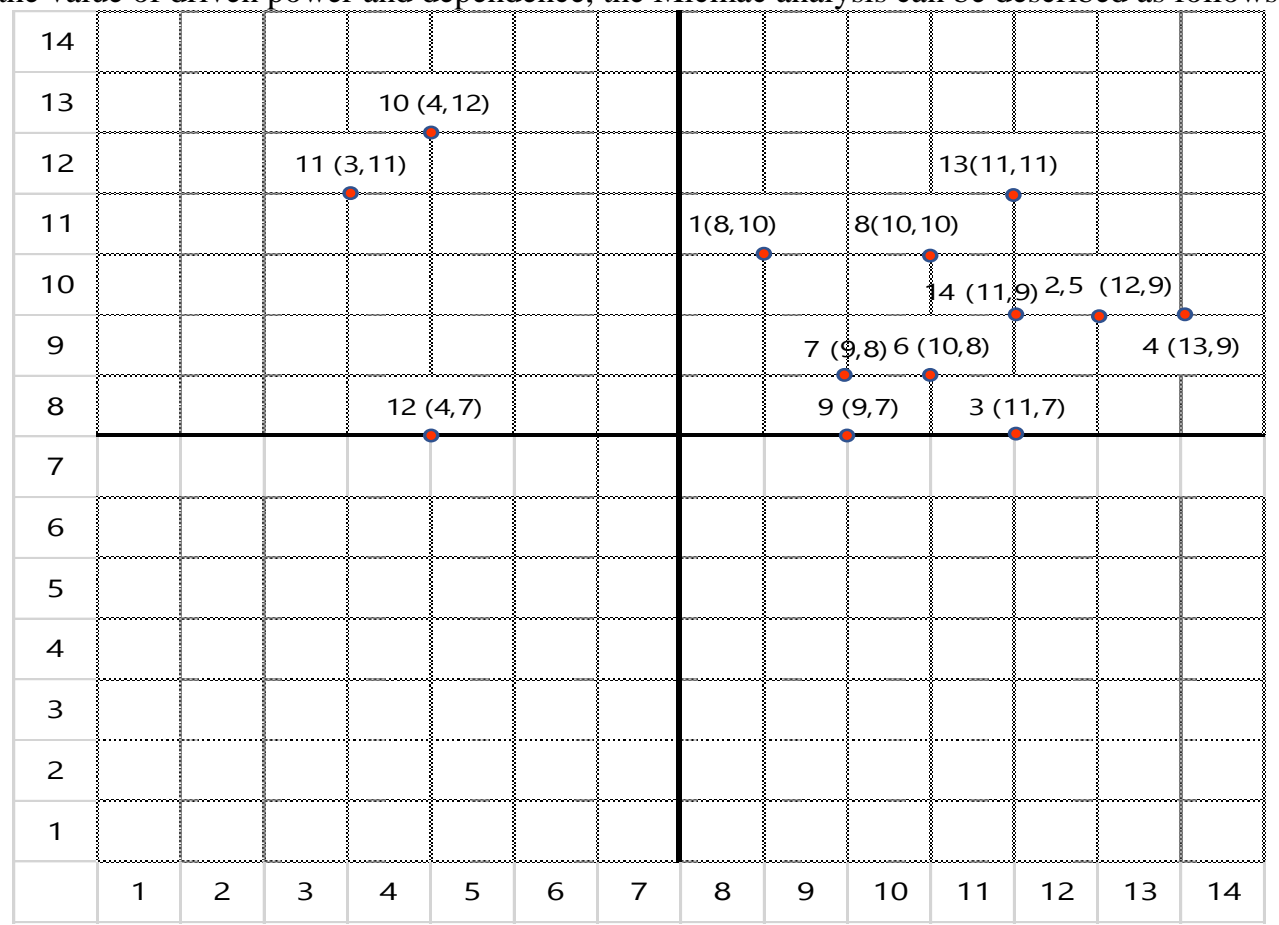

Figure 5. Driven Power-Dependence Matrix (Micmac Analysis)

\section{ACKNOWLEDGMENTS}

The authors much acknowledge the support from Brawijaya University Malang Indonesia for providing the necessary resources to this research. The authors are also grateful to the anonymous reviewers and journal editorial board for their many insightful comments, which have significantly improved this article.

\section{REFERENCES}


Bahruddin, M., \& Nugraha, E. F. S. (2013). Masyarakat Kampoeng Batik Jetis Sidoarjo: Antara Mempertahankan Batik Tulis Sebagai Produk Budaya Lokal Dan Kontribusi Ekonomi. Seminar Nasional \& Workshop : Peningkatan Inovasi Dalam Menanggulangi Kemiskinan, 143-150. Sidoarjo: LIPI.

Baumann, H., Boons, F., \& Bragd, A. (2002). Mapping the green product development field: engineering, policy and business perspectives. Journal of Cleaner Production, 10(5), 409-425. https://doi.org/10.1016/S0959-6526(02)00015-X

Charter, M., \& Clark, T. (2007). Sustainable Innovation Key conclusions from Sustainable Innovation : Conferences 2003-2006 organised by The Centre for Sustainable Design.

Chen, Y.-S. (2008). The Driver of Green Innovation and Green Image - Green Core Competence. Journal of Business Ethics, 81(3), 531-543. https://doi.org/10.1007/s10551-007-9522-1

Dangelico, R. M., \& Pujari, D. (2010). Mainstreaming Green Product Innovation: Why and How Companies Integrate Environmental Sustainability. Journal of Business Ethics, 95(3), 471-486. https://doi.org/10.1007/s10551-010-0434-0

Diabat, A., Govindan, K., \& Panicker, V. V. (2012). Supply chain risk management and its mitigation in a food industry. International Journal of Production Research, 50(11), 3039-3050. https://doi.org/10.1080/00207543.2011.588619

Elim, L. (2018). Gema : Industri Kecil (60th ed.). Jakarta.

Grant, R. (1999). The Resource-Based Theory of Competitive Advantage: Implications for Strategy Formulation. In Knowledge and Strategy (pp. 3-23). https://doi.org/10.1016/B978-0-7506-70883.50004-8

Jin, Y., Hopkins, M. M., \& Wittmer, J. L. S. (2010). Linking human capital to competitive advantages: Flexibility in a manufacturing firm's supply chain. Human Resource Management, 49(5), 939-963. https://doi.org/10.1002/hrm.20385

Kamil, A. (2011). Pelaksanaan Kebijakan Pembangunan Industri Prop. Jawa Timur. Retrieved from Wordpress website: https://anathakamil.wordpress.com/2011/09/30/pelaksanaan-kebijakanpembangunan-industri-prop-jawa-timur/

Kemp, A. A. and R. (2009). Measuring eco-innovation. Keizer Karelplein.

Kurniawan, M. W., Purwanto, P., \& Sudarno, S. (2014). Strategi Pengelolaan Air Limbah Sentra Umkm Batik Yang Berkelanjutan Di Kabupaten Sukoharjo. Jurnal Ilmu Lingkungan, 11(2), 62. https://doi.org/10.14710/jil.11.2.62-72

Marshal, R. (2012). Penerapan Energi Efisiensi di IKM. Workshop Efisiensi Energi Di Sektor Industri Kecil Dan Menengah, 1-25. Jakarta: PPBN.

Mizar, M. A., Mawardi, M., Maksum, M., \& Rahardjo, dan B. (2008). Tipologi Dan Karakteristik Adopsi Teknologi Pada Industri Kecil Pengolah Hasil Pertanian. Prosiding Seminar Nasional Teknik Pertanian. Yogyakarta: Seminar Nasional Teknik Pertanian.

Nunes, B., \& Bennett, D. (2010). Green operations initiatives in the automotive industry. Benchmarking: An International Journal, 17(3), 396-420. https://doi.org/10.1108/14635771011049362

Nurainun, Heriyana, \& Rasyimah. (2008). Analisis Industri Batik Di Indonesia. Fokus Ekonomi (FE), 7(3), $124-135$.

Pawitan, G. (2012). Characteristics of Small Medium Manufacturing Industries In the Era of ACFTA: Case Study from West Java. Procedia Economics and Finance, 4, 130-139. https://doi.org/10.1016/S22125671(12)00328-0

Pradito, D., Jusuf, H., \& Atik, S. K. (2010). The Dancing Peacock (W. D. Harti, Ed.). Jakarta: Gramedia Pustaka Utama.

Ramelan, R. (2008). Sebuah Tulisan Mengenai Batik : Industri Batik Dan Permasalahannya. Retrieved from rumahumkm.net website: http://www.rumahumkm.net/2015/12/sebuath-tulisan-mengenai-batikindustri.html

Republika.co.id. (2009). Pasca Pengakuan UNESCO, Penjualan Batik Yogya Naik 30 Persen. Retrieved from Republika.co.id website: https://republika.co.id/berita/breaking-news/ekonomi/09/12/05/93554-pascapengakuan-unesco-penjualan-batik-yogya-naik-30-persen

Rimantho, D., \& Rosdiana, H. (2018). Penentuan Faktor Kunci Peningkatan Kualitas Air Limbah Industri Makanan Menggunakan Interpretative Structural Modeling (ISM). Jurnal Ilmu Lingkungan, 15(2), 9095. https://doi.org/10.14710/jil.15.2.90-95

Rochma, N., \& Titah, H. S. (2017). Penurunan Bod dan Cod Limbah Cair Industri Batik Menggunakan Karbon Aktif Melalui Proses Adsorpsi Secara Batch. Jurnal Teknik ITS, 6(2), 324-329.

Santoso, P. B., \& Darwanto, D. (2015). Strategy for Strengthening Farmer Groups by Institutional Strengthening. Jurnal Ekonomi Pembangunan: Kajian Masalah Ekonomi Dan Pembangunan, 16(1), 33-45. https://doi.org/10.23917/jep.v16i1.936 
Shanti, U. A., \& Ratyaningrum, F. (2016). Pengembangan Motif Batik Di Ud. Batik Satrio Manah Kabupaten Tulungagung. Jurnal Pendidikan Seni Rupa, 4(2), 253-259.

Sumadyo, M. (2016). Penggunaan Teknik Analisis Dalam Pengembangan Sistem Informasi Menggunakan Soft System Methodology (SSM). Jurnal Penelitian Ilmu Komputer, System Embedded \& Logic, 4(1), 36-48.

Tjahjani, Hatta, \& Wahyudi. (2018). Community Partnership Program to Increase Competitiveness of Batik Tulis in Kampoeng Jetis Sidoarjo. Kontribusia (Research Dissemination for Community Development), 1(2), 14. https://doi.org/10.30587/kontribusia.v1i2.619

Tjahjani, I. K., Mochammad Hatta, \& Wahyudi, A. (2017). Peningkatan Kemandirian Pengrajin Batik Tulis Kampoeng Jetis dan Kesejahteraan Masyarakat Sekitar Melalui Program PKM. Prosiding SNTI Dan SATELIT, 298-304. Batu: Jurusan Teknik Industri Universitas Brawijaya.

Tjahjani, Ida Kusnawati, Baharuddin, F., \& Yuliawati, E. (2019). Strategi Mempertahankan Eksistensi Batik Tulis dan Peningkatan Daya Saing Pengrajin di Desa Sekardangan Sidoarjo. JPP IPTEK (Jurnal Pengabdian Dan Penerapan IPTEK), 3(1), 51-60. https://doi.org/10.31284/j.jpp-iptek.2019.v3i1.483

Wardani, L. K. (2015). Menggali Potensi Sentra Industri Kreatif Sidoarjo, Jawa Timur. Peran Strategis Seni \& Budaya Dalam Membangun Kota Kreatif, 1-15. Malang: Universitas Malang.

WartaEkonomi.co.id. (2018). Kemenperin: Ekspor Batik Sentuh US\$58,46 Juta.

Wu, H.-Y., Lin, Y.-J., Chien, F.-L., \& Hung, Y.-M. (2011). A study on the relationship among supplier capability, partnership and competitive advantage in Taiwan's semiconductor industry. International Journal of Electronic Business Management, 9.

Yuan, C., \& Zhang, T. (2013). Environmental Implications of Nano-manufacturing. In Green Manufacturing (pp. 179-202). https://doi.org/10.1007/978-1-4419-6016-0_8 